\title{
The Meaning of Truant Behavior for Junior and Senior High School Students in Indonesia
}

\author{
Siti Atiyyatul Fahiroh ${ }^{1 *}$ \\ ${ }^{1}$ Faculty of Psychology, University of Muhammadiyah Surabaya, Surabaya, Indonesia \\ *Corresponding author. Email: atikfahiroh@gmail.com
}

\begin{abstract}
Truant behavior has become a national concern that requires attention. In general, truant behavior is often explored mainly from the perspective of parents, teachers, and society who views students as being at fault. Very few have observed this phenomenon from the students' perspective. This study aimed to understand what truant behavior means to junior and senior high school students. This research is a qualitative study using a phenomenological approach. The data were analyzed following Miles and Huberman's model. The data were collected through an interview. The inclusion criteria for participant selection include: (1) active junior and senior high school student, (2) performed a form of truant behavior for more than six months. In total, there are three participants involved in this study. The findings reveal that junior and senior high school students interpret the meaning of truant behavior into at least one of three categories: troublesome value, a solution to helplessness, and a form of peer conformity. This study suggests that parents, as well as guidance and counseling teachers, need to understand the reasons why students conduct truant behavior and how to handle such occurrences among junior and senior high school students.
\end{abstract}

Keywords: truant behavior, school psychology, truancy

\section{INTRODUCTION}

The phenomenon of truant behavior recently is increasingly prevalent among adolescents or junior and high school students. The symptoms of truant behavior among high school students are playing at PlayStation or internet cafe, hanging out and gathering with their playmates who do truant during class [1]. Truant behavior is done by means of not going to school for full day, coming to school but not following the lessons as the schedule set or escaping from teaching and learning activities [2]. The truant behavior develops easily into behavior with continuous symptoms by permanent absence in the school [3]. This behavior is going to cause failure in academic learning at study, because it cannot complete the subject matter at that time [1]. Truant behavior can also cause maladjustment, low academic achievement, drop out school and delinquency [4]. Therefore, truant behavior needs more attention. Truant behavior cannot be understood as an individual phenomenon, but as a complex process of interaction between adolescents and parents, peers, teachers, and school staff [3].

In general, researchers and observers perceive truant behavior from a negative perspective. This study attempts to understand truant behavior as interpreted by the perpetrators themselves. By understanding truant behavior from the perspective of perpetrators, causal factors and dynamics of such behaviors can be further understood. This understanding will, in turn, assist related parties to solve the problem of truancy which is now debatably a national problem in the domain of education, considering that middle school students are the nation's future assets who will replace the current productive generation.
The term "truancy" according to K. Reids, et.al is often misinterpreted and generally applied to local contexts [5]. In some areas of Britain, truancy is known as dodging, skipping, mitching, leaving work, skiving, bunking, and going missing. Truancy as absenteeism is not authorized by the school as well as leaving school without consent. Another definition given in W. Andrew Collins and Brett Laursen, stated that truant behavior is when a student who is registered at a school does not attend school even though attendance is obligatory [6] [7]. This definition includes absence in special subjects.

Truancy is an individual's response or reaction that is manifested in the decision to leave lessons during school hours and be absent from teaching sessions and the learning process at school [8]. From some of the notions of truant behavior above, it can be concluded that truant behavior is absenteeism from class, leaving classes which are still taking place, being absent from teaching and learning process without permission from the class instructor.

There are four causative factors of truant behavior that should be understood [9]. The first factor that causes truancy is the demographic factor which is considered a relatively established perspective. Several pieces of literature question the opinion of a group of experts who believe that truancy tends to be more common in men, while another group of experts' states that tendency for truancy is equal in both men and women. Minority students are traditionally more likely to have chronic truancy in comparison to Caucasian students.

Past studies have found certain races to have higher likeliness for truancy. Statistically, truancy is found to affect $30 \%$ of Hispanics or Latino children and $20 \%$ of the Black races. Minority statuses, such as urban youth, low family income, children living with only one parent, children from 
large families, and children with less-educated parents are at a higher risk of being chronically truant.

The second factor is the family characteristics [9]. While demographics can help identify truant students, one of the most significant factors that influence truancy is the parental perception of education. Parental involvement in school and homework results in better school attendance. Conversely, students whose parents embrace the view that children may leave school for family reasons (e.g. caring for younger siblings or working to support family income) have a high tendency to play truant. Findings showed that students who play truant generally come from single-parent families and have more siblings than students who do not play truant. More than $90 \%$ of children who play truant have families with high-stress levels.

The third factor is the individual and psychological factors [9]. Individual and psychological traits of students have a significant influence on the daily decisions to attend school - some students who play truant share some of the same individual and psychological problems. Students who skip school tends to have low self-esteem, low social skills, and scarce friendship. Students' perceptions about the school and classroom environment will also significantly determine whether or not the child decides to attend school.

School Climate is the fourth causal factor of truant behavior [9]. School climate, including attachment to teachers, truancy policy, and feelings of physical comfort will all affect students' motivation to attend school. Several factors that influence the emergence of truant behavior are electronic media, family, school climate, student, peers, and teachers [10].

Media electronic is also a factor that influences truancy. Students may engage in electronic games that consume time due to it being especially entertaining, causing them to spend more time engaging in fun activities relative to their school attendance. Students may have initially started playing computer games to reduce the stress of learning but got carried away. Students who skip school often come to entertainment places as they are usually an ideal place for meeting friends. Engagement in entertainment and changes $\mathrm{n}$ children's lifestyle patterns are mostly influenced by twenty-four-hour television broadcasts and other electronic media.

Family factors include parents who are rarely at home due to busy work schedules, parents transferring responsibility to caregivers, parents going overboard in encouraging their children to study, parents who often fight at home, parents who are less concerned with whether or not their children go to school, parents who provide complete facilities at home, and parents who love other family members more than the child concerned.

School climate factors include the classroom convenience such as comfort of desks and chairs, whether or not there are other students who interfere with the concentration of their peers during the learning process, the quality of relationship between teachers and students, level of pressure to learn, whether the school provides opportunities for regular parentteacher meetings, whether or not the class atmosphere is pleasant, whether or not the school provides a proper place for students to rest, sense of comfort with the school environment, whether or not the extracurricular classes are considered burdensome, school rules that are not too strict, provision of appropriate facilities and equipment for students and food canteens that does not suit student's taste and wallet (expensive).

Student factors include whether the student attends school only due to parent's coercion or do so voluntarily, feeling disappointed by exam or test results, more interested in working rather than learning, no interest in school due to perception of unimportance, feeling fed up or bored with particular subjects, do not enjoy reading school textbooks, (in)ability to survive in the classroom and face strict teachers, frequently falling asleep or waking up late so late for school, and preferring entertainment than learning.

Peer group factors include being teased or bullied due to academic failure, being easily persuaded by friends to have fun instead of learning, going to malls during school hours, having the desire to be absent from school, openness to sharing problems with peers and conversely ability of peers to listen when a friend is faced with a problem, pride of having capable and influential peers, and preference to imitate the style of popular or influential peers.

Teacher factors includes having a teacher who is engaging, fun and has a pleasant attitude when teaching, teachers who are considerate when dealing with students who misbehave, teachers who give a lot of homework, friendly teachers who pay attention to student's study process, teachers who impose penalties when students misbehave, teachers who often give advice during the learning process, teachers who are always there to help, teachers who always arrive late in class, as well as boring teaching and ineffective learning.

It can be concluded that several factors influence the emergence of truant behavior include demographic factors, factors related to family characteristics, students' individual and psychological factors, school climate factors, electronic media factors, peer group factors and teacher factors.

Truancy involves certain risks of participating in activities that may be considered as or lead to violations of law, for example social isolation, involvement with gangs, failure to complete education, drug abuse, delinquency, teen pregnancy, expulsion from school, and being involved with theft and obstruction of property [9]. Truant behavior is not only characterized by the number of absences. There are several characteristics of truant behavior indicated by number of absence at school, absence without permission or consent, often skipping class at certain school hours, not coming back to class after asking permission, persuading friends to skip subjects that are they do not like, asking for sick leave by pretending to be sick, sending a letter of permission to be absent school using a made-up excuse and coming back to school after recess [8].

\section{METHODS}

This study uses a qualitative approach. Qualitative approach is based on the phenomenological perspective which attempts to naturally understand a given phenomenon without specific predisposition. Qualitative study is needed, among others, when researchers seek to explore an individual's life experience related to the phenomenon studied [11].

This study used a phenomenological method. The phenomenological method explores the meaning of people's 
experience. This is consistent with the phenomenological research, which is the maintenance of the meaningfulness of experience. In line with another opinion that phenomenological research looks at an individual's interpretation of his experiences [12]. In this study the authors wanted to examine the meaning of truant behavior for middle and high school students based on their experiences as principals; thus, this study uses a phenomenological method.

The authors used Miles and Huberman's qualitative model to analyze the data. In this model, Miles \& Huberman in Emzir, presented three stages of qualitative data analysis [12]: (1) data reduction, referring to the process of selecting, focusing, simplifying, abstracting, and transforming raw data from the field notes, (2) data model, defined as a group of organized information which allows conclusion and action to be made, (3) drawing and verifying conclusion. The researchers start by collecting data, deciding on the meaning, and noting the order, causality, and propositions. In this data analysis, the researcher selected and focused on relevant data of truant behavior such describing the data to infer conclusion.

The inclusion criteria for participant selection include: (1) active junior and senior high school students, (2) performed a form of behavioral behavior for more than six months. In total, there were three participants involved in this study. The truant behavior types of participants are by not attending all day, hanging out in a cafe, arriving in the school late, leaving the school early or staying at home all day by watching television.

\section{RESULTS AND DISCUSSION}

From the data analysis, researchers found several meanings of truant behavior, which include (1) troublesome value, (2) solution to helplessness, (3) peer conformity. The present study also provides information on forms of truant behavior, reasons for engaging in such behavior, activities done during truant, and individuals' feeling when doing truant. Students believe that truant behavior portray negative values; behaviors that are uncomfortable due to guilt, embarrassing, and harmful due to loss of knowledge. This behavior also requires people to lie, be it to themselves or parents. Truant behavior is also an irresponsible act which shows laziness. For students, truant behavior can elicit anxiousness, derived from the fear of getting caught or punished.

The issue regarding values can be associated to Kohlberg's moral development, particularly at early adolescence which is also known as the conventional stage. During this stage, individuals try to commit to the norms made by others (e.g., parents, peers, leaders). Compliance towards rules are initially done to win and maintain approvals within the social system. The perspective from other people will be acknowledged and considered seriously. Next is the third stage ("Good Boy" or "Good Girl" morality) [13]. At this stage, children will determine appropriate behavior based on what would make other people happy, as well as what would help and be approved by others.

According to Kohlberg in Elaine U. Polan \& Daphne R. Taylor, school-aged children will begin to seek approval from the community at this stage [14]. Kohlberg believe that, at this phase, children are influenced by external force in the form of interaction with peers and their surroundings. A 12year-old knows that it is wrong to lie at school, wanting instead to win the approval of his or her family and teachers. This is in line with the present finding, whereby, despite conducting truant behavior, students still viewed it as a bad deed that deserves punishments.

Truant behavior is also done by students to deal with feelings of hopelessness. For example, students who are frequently bullied by their peers could feel deeply hurt and incapable of facing their bullies. They tend to avoid attacking back or reporting the bully perpetrators to teachers because they feel bad if their friend gets punished by teachers, opting instead to skip school for several days. They can express their frustration at home by breaking glasses, watching movies, playing games, watching YouTube, while still maintaining to study. This behavior is related to adolescents' coping style. Coping is a specific response that individuals show to manage certain stress that they experience [15].

Each individual has a different coping mechanism, which shows their unique adaptation skill. There are two types of self-adaption toward (1) weakening the symptoms of stress, both unconsciously (e.g., ego defense mechanism) and consciously (e.g., talking about the problem to someone, doing other activities that induce laughter), (2) attempting to more directly manage the source of stress, also called as effective adaptation. For the latter, participants often use the denial defense mechanism to avoid looking or hearing about unpleasant or threatening realities and dismiss external approval or social reality. The above finding shows that hopelessness can trigger truant behavior among students. One of the reasons for skipping school is the school climate [10]. This is in line with students' report, claiming that students in a lower position and feels hopeless often engage in truant behavior. This is because, being in the bottom of the class causes students to feel demotivated to go to school; thus, missing out on lessons in class. Being in the bottom does not always refer to the rating in class. Students who feels that their complaints will go unheard by the school does not receive enough attention or response from the school. In other words, being in the bottom of the school system can also mean that students do not feel that they have power in the middle of their school peers.

Truant behavior could also be used by students to fulfill their need to affiliate with friends. In line with the characteristic of their developmental stage as adolescents, the authors found high level of peer conformity particularly among junior high school students. At this early adolescence stage, boys are scared to be compared to girls if they refuse to skip school. Adolescents are scared of being perceived as showing no solidarity with their friends who skips school. Additionally, adolescents need to feel comfortable by hanging out with their friends. This happens because, for adolescents, peer groups act as the main indicator of popularity, status, prestige, and acceptance (American Psychological Association, 2002). During adolescence, most of their time is spent with peers; thus, increasing peer conformity and the insecurity over being accepted by the group.

The forms of truant behavior found in the present study include coming late to school, skipping the first and last hour, sleeping in class which causes the student to miss out 
[4] B. Rivers, "Truancy: Causes, Effects, and Solution," Fisher Digital Publications, New York, 2010. be sleeping in the library or school mosque. The activities done when skipping school can include spending time at a coffee shop, hanging out with friends, wandering around, and making promises to play at a friend's house.

Several reasons for conducting truant behavior was found in the present study: waking up late, difficulty waking up on their own, coming late to school, the teacher being absent, bored with the material, having teachers that make students write or memorize a lot of materials, short-tempered teachers, bored of the teach, feeling hungry and exhausted.

\section{CONCLUSION}

In accordance to the purpose of the present phenomenological study of trying exploring the meaning of truant behavior based on several perpetrators, the study found that junior and senior high school students still believe that truant behavior depicts a negative value. In other words, truant behavior is seen as a bad deed, lying to oneself, lying to parents, showing laziness, making one at a disadvantage from losing knowledge that should have been acquired. Additionally, truant behavior also triggers the fear of getting punished.

Truant behavior could also be used by students to fulfill to affiliate with peers. This is in line with the early adolescence developmental stage, whereby the need to conform is high. Truant behavior can be a way to cope with stress due to feeling helpless at facing their problem.

This study suggests that parents, as well as guidance and counseling teachers, need to understand the reasons why students conduct truant behavior and how to handle such occurrences among junior and senior high school students.

\section{ACKNOWLEDGMENT}

I'm grateful for the support of school counselors' students as participants who have assisted and participated in this study. My two students are Husnol Hotimah and Nur Aida Tias Pratiwi who have helped during the research process.

\section{REFERENCES}

[1] Sariyasni dan Budiyono, "Studi Tentang Perilaku Membolos Pada Siswa SMA Swasta Di Kabupaten

Banyuasin," in Proceeding Seminar Nasional

Pendidikan, Palembang, 2019.

[2] H. R. U. Siahaan, "Membolos dan Cabut Kelas," Jurnal osial Dan Politik, 2019.

[3] Gil Keppens \& Bram Spruyt, "The development of persistent truant behavior: an exploratory analysis of adolescents' perspectives," Journal of Educational Research, vol. 59, no. 3, pp. 353-370, 2012.
[5] K. Reids, Truancy and Schools, London: Routledge Falmer, 1999.

[6] W. Andrew Collins dan Brett Laursen, Handbook of Adolescent psychology: Parent-Adolescent relationships and influences, New Jersey: John Wiley \& Sons, Inc, 2004.

[7] K. Reids, Truancy and Schools, London: Routledge Falmer, 2005.

[8] Mahmudah, "Mengurangi Perilaku Membolos Siswa Dengan Menggunakan Layanan Konseling Behavior," Jurnal Ilmiah Pendidikan Bimbingan Dan Konseling, vol. 1, no. 1, pp. 63-73, 2013.

[9] L. A. Trujillo, "School Truancy: A Case Study of A Successful Truancy Reduction Model In the Public Schools," UC Davis Journal of Juvenile Law \& Policy, vol. 10, no. 1, pp. 69-75, 2006.

[10] Asmawati Suhid, Abdul Rahman, dan Norliana Kamal, "Factors causing student absenteeism according to peers," International Journal of Arts and Commerce, vol. 1, no. 4, pp. 342-350, 2012.

[11] Juliet Corbin dan Anselm Strauss, Dasar-dasar penelitian kualitatif, Yogyakarta: Pustaka Pelajar, 2003.

[12] Emzir, Metode Penelitian Kualitatif Analisis data, Jakarta: Raja Grafindo Persada, 2012.

[13] Carol K. Sigelman \& Elizabeth A. Rider, Life-span human development Sixth Edition. :, Canada:

Wadsworth, Cengage Learning, 2011.

[14] Elaine U. Polan \& Daphne R. Taylor, Journey Across the Life Span: Human Development and Health Promotion, Philadelphia: F. A. Davis Company, 2007.

[15] K. S. Dewi, Buku ajar kesehatan mental, Semarang: Lembaga Pengembangan Dan Penjaminan Mutu Pendidikan Universitas Diponegoro, 2012. 